\title{
Russian-Lithuanian Relations: Between Negative Perception Stereotypes and Pragmatic Cooperation
}

\begin{abstract}
Lithuania's accession to the EU and NATO predetermined a new stage for Lithuanian-Russian relations. However these relations are still accompanied with a negative and suspicious attitude. Despite the number of contacts on various political levels and the functioning mechanisms of bilateral cooperation, and by content, featured by the implementation of mutually beneficial economic projects, are on a definitely high level. Therefore the author argues that in major issues of Russian-Lithuanian interaction, the balance between negative stereotypes of perception and interests of pragmatic cooperation are drifting in favour of the latter. In the long-term optimistic scenario, the factor of negative mutual perceptions is going to weaken, thus decreasing the opportunities for utilizing it in domestic politics. Relationships between Russia, the EU, and the U.S.A. alongside with keeping elements of competition are doomed for cooperation and probably partnership, reducing the demand for criticism towards Russia. So, the Baltic States will confront with necessity, the building of a cooperative model of relationships with their Eastern neighbour. The development of economic and humanitarian links, in particular on a regional level, serves as a precondition for overwhelming mutual negative images and fostering political dialogue between Russia and Lithuania.
\end{abstract}

\section{Introduction}

The political, territorial, social, and cultural interaction and transfusion between Russians and Lithuanians has a centuries-long history. But the current stage of Russian-Lithuanian relations - which started at the end of 1980's to the beginning of 1990's - may qualify as phenomenal insofar as they have been developing in a qualitatively new geopolitical reality and foreign policy context.

It is logical to raise a question about the priority of the ranking of relationships between each other for both Russia and Lithuania and the answer is likely to be asymmetric. This is due to the fact that for Lithuania, in spite of the proclaimed integration into Euro-Atlantic structures and successfully reaching the end of accession to the EU and NATO, Russia still remains a meaningful

\footnotetext{
* Dr. Leonid Karabeshkin is a Chairman of the Baltic Club (St. Petersburg, Russia) and Associate Professor of the Eurouniversity (Euroülikool) in Tallinn, Estonia. Address: P.O. Box 488, 191123 St Petersburg, Russia, tel. +372 6115229, e-mail: baltclub@mail.ru
} 
economic partner and political reference point, though often with some negative sides too. For Russia (except the very limited North-West regional group) in terms of trade turnover (this is the argument that used to be regularly mentioned by the Russian leaders, when characterizing relations with other states) Lithuania is of marginal importance. Nevertheless, it should be recognized that the magnitude of the relationship with Lithuania, for Russia, exceeds the scope of its economic weight. This is caused by both traditional and relatively newly emerging reasons.

Firstly, there is a long period of common history and co-existence in the framework of a common state and also a formed system of economic links in a broad range of sectors, in particular, the energy sector (including nuclear energy), and transport and transit sectors. The level of economic interdependence, that emerged during the Soviet time, was even more than between Russia and many other republics of contemporary CIS.

Along with the economic dimension, the key meaning has been assumed by the politico-psychological one. Relationships with Lithuania (as well as with other Baltic States) play the role of a "thermometer" for processes of domestic political transformation and a searching place in the world. Keeping in account the obvious existence of mutual perception complexes (not always and not all positive ones) both in Lithuania and Russia, then one may conclude that Russian-Lithuanian relations are important not only by the virtue of, but as well as, in spite of enjoying a common history.

Secondly, Lithuania is a neighbouring state, of Russia, bordering not the mainland territory, but the Kaliningrad enclave which is even more important. Alongside the natural desire of any country to have stable, and at least not adversary, regimes around the perimeter of its borders, a kind of a "goodneighbourhood belt" versus a cordon sanitaire, cooperation with Lithuania is important with the axis of providing the Russian status of the Kaliningrad Oblast. The top cooperation agenda for the Kaliningrad area is occupied by the issues of "access" - such as passenger, cargo, military transit, transportation of raw materials and energy - which in the Russian political vocabulary has constituted of a "basic subsistence" of the Kaliningrad Oblast.

Thirdly, alongside with the "traditional" factors, new ones tend to affect Russian-Lithuanian relations. Accession to the EU and NATO predetermined the new stage of Lithuania's foreign policy. On one hand, Lithuania is striving to play a more active role in the Euro-Atlantic groupings, by influencing inter alia formulation and the implementation of policies of these organizations towards Russia. On the other hand, with account of its relatively small territory, population, and the economic potential as well as of peripheral geographic location, Lithuania realized the need to look for a "specialized niche" in framework of European politics. Lithuania set a goal for the promotion of its regional status and capitalizing on its "expert" role in the post-Soviet space, first and foremost in the European republics of CIS and South Caucasus, which are treated in Russia as a zone of traditional influence. Lithuania's line has been supported and stimulated from Washington, which transformed its North European Initiative (NEI) into e-PINE - "Enhanced Partnership in Northern Europe" and 
affected the EU initiative "Wider Europe-New Neighbourhood" elaboration, furthered by the European Neighbourhood Policy (ENP).

Nevertheless, the growing activism of the EU and USA in the region of CIS was accompanied with a negative and suspicious attitude towards the aforementioned initiatives in Moscow has not led to a serious deterioration in Russian-Lithuanian relations. The number of contacts has taken place at the highest political level, there are functioning mechanisms of bilateral cooperation, and by content, featured by the implementation of mutually beneficial economic projects, and these are on a definitely higher level than Russia's relations with other Baltic States. The author argues that this is reasoned by the fact that in the major issues of Russian-Lithuanian interaction the balance between negative stereotypes of perception and interests of pragmatic cooperation is drifting in favour of the latter. In this article the author tends to show the controversial implications of this balance by reviewing different aspects of economic cooperation, and also the domestic and foreign policy of Russia and Lithuania.

\section{Economics of the Russian-Lithuanian Relationship}

Throughout the last decade and a half, Russia has been the leading trade and economic partner of LR. According to Lithuanian statistics, in 2005 Russia occupied the first place rankings both in exports (10.4\%) and imports (27.8\%). A similar situation remained for $2006-11.3 \%$ and $27.9 \%$ respectively for January through July of $2006{ }^{1}$

The traditional sphere of Russia's interest in cooperating with Lithuania are fuel and energy, as well as transport and transit. Russia almost entirely covers the gas balance of Lithuania, granting more competitive prices than for the rest of the EU (105 USD to 135 USD per thousand cube meters in 2006) ${ }^{2}$. Besides, the entire gas transit to the Kaliningrad Oblast is performed through Lithuanian territory. The Russian gas monopoly "Gazprom" has a stake of control in gas retailers "Lietuvos Dujos" and "Dujotekana" and purchased the Kaunas TPP. Besides, direct agreements provides for privileged conditions for the gas supply to the Lithuania's chemical giant "Achema." It is noteworthy that Lithuania became the first country where "Gazprom" entered the electricity generation business. Alongside with the officially stated purpose of business diversification and penetration into the Lithuanian energy market, which is getting more attractive after termination of the Ignalina Nuclear Power Plant, "Gazprom" reportedly pursued the goal of starting to export to the Kaliningrad Oblast. This would help "Gazprom" to decrease the volume of gas to be sold at a much lower domestic price to another Russian monopoly RAO "UES" for

\footnotetext{
${ }^{1}$ Counted by data from the Department of Statistics LR, http://www.std.lt

2 "President Litvy Nagovoril Na \$30: Gazprom Prodolzhaet Povyshat' Ceny", Kommersant, May 5, 2006.
} 
the Kaliningrad TPP-2. ${ }^{3}$ The probability of this scenario is confirmed by the draft of the "Gazprom" Investment Memorandum".

Cooperation in the gas sphere, and access of the Russian state monopoly to privatization in Lithuania, witnesses about the pragmatic long-term calculation on behalf of Lithuania to utilize the natural advantage of its geographic location - the proximity to the resources of fossils. At the same time, the story with the double privatization of "Mažeikių Nafta" (MN) is an example of another sort, where the political factors played against the economic benefits. It is well known that after unsuccessful ownership of American "Williams" in 2002, the refinery found itself under the control by Russian oil company YUKOS, which invested into its modernization and provided a stable oil supply and profitability. The bankruptcy of YUKOS caused by the steps of the Russian leadership, forced the company to sell its assets, including the Lithuanian subsidiary. It became unavoidable when YUKOS lost the quota for oil pumping through the pipeline system of state-controlled "Transneft."

There was an impression that the issue of the foreign assets of YUKOS, including $\mathrm{MN}$, had a peripheral meaning during the process of its parcellization. The transfer of this property directly to one of the Russian oil companies ("Rosneft" as the main debt holder) was complicated by the fact that formally, property rights belonged to the YUKOS "daughter" company, registered in Holland. Though Russian companies "LUKoil" and TNK-BP took part in the tender on $\mathrm{MN}$, their bids proved to be uncompetitive. The best offer was proposed by Polish "PKN Orlen" which defeated "KazMunaiGaz" from Kazakhstan, though the latter proceeded with attempts to outbid MN. After that the accident on the trunk pipeline a "Friendship" happened, what resulted in the reduction of oil pressure and switching off the branch to Biržai. The Russian authorities insist that the pipeline needed a long-term restoration, thus producing speculations on the political motives of the "accident."

The interest of Russian companies, and even competition between them, over control of MN looks natural in context to Russia's energy strategy, which stipulates the shaping of strong vertically integrated national energy companies with a world-wide presence. But though the shortage of modern refineries is obvious, Russian companies were not eager to overpay for $\mathrm{MN}$, while the finalists - PKN "Orlen" and "KazMunaiGaz" were ready to offer "political" premiums for entrance into the new markets of oil procession and transit.

The "avarice" of Russian companies might be explained by a number of considerations. First of all, they could have decided that Polish and Kazakh companies would fail to provide for a condition of stable oil supply, whereby the majority of observers, including representatives of Lithuanian political elite, realized that none but Russia could be a source of raw materials. The alternative options such as oil import through the Būtinge oil terminal would negatively affect the effectiveness of oil refining, putting it under risk in case of a serious fall in oil prices. The Russian companies will hardly be enthusiastic

\footnotetext{
${ }^{3}$ Butrin D., Vodo V., "Litva proschaetsia s "Lietuvos dujos", Kommersant, March 25, 2004.

${ }^{4}$ Cf.: http://www.akm.ru/rus/news/2006/october/17/ns1795851.htm
} 
about providing a stable supply for a refinery which is out of their control. The problem may exacerbate due to the potential shortage of oil on the Western direction in context of the prospective construction of the pipeline to China. This paradoxically increased the chances of "KazMunaiGaz" to agree with Russia on oil transportation to Lithuania, because Russia is getting more interested in substitute oil flows westwards, which may originate first of all from Kazakhstan ${ }^{5}$. Besides, the high level of relationships between Russia and Kazakhstan between N. Nazarbaev and V. Putin - as well as the intertwined interests of Russian energy companies in Kazakhstan could contribute to settling the issue. Nevertheless, Russian companies managed to lobby abrogation of the oil transportation quota through the "Transteft" system for "KazMunaiGaz" in November 2005. ${ }^{6}$ All of this was to have convinced the Lithuanian Government to support one of the Russian companies in the tender.

Though officially, the Lithuanian Government was not a party in the negotiations on selling shares of $\mathrm{MN}$, it explicitly tried to pursue its preferences. The transfer of control to a Russian company was not a preferable option for Lithuania. The former minister of foreign relations A. Valionis openly claimed that the "sale of MN to Poland is a fact of extraordinary geopolitical importance, it is not only a commercial project, but an element of geopolitical battle, where success or failure would be of utmost importance for us." ${ }^{\prime 7}$ Seemingly, it is referred to as a battle for Lithuania's independence from Russian oil supplies, which according to some Lithuanian experts, may be gained through the creation of the united Central European oil concern by means of the amalgamation of Polish, Hungarian, Austrian, and Lithuanian companies. ${ }^{8}$

Presumably the position of the Lithuanian Government was as well affected by the again sparked "Russian question." Some political forces in Lithuania tend to interpret naturally what is explicitly declared by Russian companies and the state's desire to widen their presence on the European market and take their niche as the world energy leader as an attempt of Russia to project its "illegitimate" influence on Lithuania through dummy firms. In this context "Mažeikių Nafta" was presented as a centre of financing for subversive activities.

But it would be an oversimplification and exaggeration to view Russian national interests in supporting the foreign expansion of the Russian energy sector exclusively for the purposes of putting Lithuanian domestic politics under control. Russia's interest is rather aimed at decreasing political and economic risks of delivering energy resources to the West and supporting strategic investment of Russian companies abroad. The latter is of special importance

\footnotetext{
${ }^{5}$ Zaslavsky I., "Delo truba. Baku - Tbilisi - Ceyhan i kazakhstanskii' vybor na Kaspii", Moscow: Europe, 2005. p. 71.

6 "Veselye sosedi. Khoroshie druz'ia", Expert, no. 44. November 21, 2005. http://www.expert.ru/printissues/ expert/2005/44/44ex-pov11

${ }^{7}$ BNS, "A.Valionis: "Mažeikių naftos" pardavimas Lenkijai - geopolitinio mūšio dalis", September 5, 2006

${ }^{8}$ Janeliunas T., Molis A. "The NGEP Ends Lithuania's Hopes of Becoming a Transit Country", Baltic Mosaic, 2005, no. 1. p. 30-31.
} 
with account to the psychological factors behind some of the recent failures, e.g. the unlucky story of the merger "Severstal" and "Arcelor".

The project 2K aimed at coordination of the Kaliningrad and Klaipeda ports has as well suffered from accusations related to activities of special services. It was initiated in 2000, but in 2003 the Lithuanian Department of State Security brought accusations that it was used for establishing Russian control over transit and withdrawing Russian transit cargoes from Klaipeda to Kaliningrad. Indeed, between 2000 - 2004 the share of Russian cargoes in cargo turnover at the Port of Klaipeda fell down about 5 times or by $5.3 \% .{ }^{9}$ But this took place when the project existed in a form of declarations rather than practical implementation. At the same time it should be recognized that Russian and Lithuanian approaches towards implementation of $2 \mathrm{~K}$ are disaccording, when the very project contains a number of in-built contradictions. For instance, Lithuanian railways and the Port of Klaipeda act as competitors meaning that the reorientation of cargoes towards Kaliningrad is lucrative for the former.

After signing the Agreement on Cooperation in Implementation of the $2 \mathrm{~K}$ project (May of 2005, Trakai), the trend of growing Russia's cargo share in Klaipeda has manifested and accordingly in 2005-2006 it increased 43\% and $64 \%$ respectively. ${ }^{10}$ Though the contribution of the $2 \mathrm{~K}$ project to this growth can hardly be properly identified, it sends a positive impetus for business and evidences about the long-term intentions of Russia and Lithuania to cooperate in the transport and transit sphere. The significance of the project was pointed out by President V. Putin during his visit to Kaliningrad (in September of 2006): “What concerns our relationships with Lithuania in this sphere is that we both have no alternatives to joint efforts. I do not think that everything there (in the $2 \mathrm{~K}$ project - L.K.) has finally been arranged and functioning as we agreed, but I rely that as a result of collaboration all impediments will be removed." 11 The head of the Russian railway company " $\mathrm{RZhD"} \mathrm{Vladimir}$ Yakunin identified the Lithuanian direction as the most perspective for transit cargo flows though railways, predicting a 40\% growth in $2005-2010^{12}$.

The recently revived criticism of $2 \mathrm{~K}$, catalyzed as well by domestic developments in Lithuania, is evidence of the attempts of utilizing political (or even geopolitical) factors in economic competition. Accompanied by the process of the privatization of "Mažeikių Nafta," it resulted in a severe worsening of the psychological environment of Russian-Lithuanian relations and excessive politicization of their economic component. Lithuania suspects that Russia may attempt an intentional cut off of the pipeline and hints that the Lithuanian railways as well need renovation, thus jeopardizing the stability of transit to the Kaliningrad Oblast. Russia, in turn, demonstrates an independence from Lithuanian transit routes by pompously opening the railway ferry between Ust-Luga (Leningrad Oblast) and Baltijsk.

\footnotetext{
${ }_{9}^{9}$ Manomaitite M., "Podpisanie proekta 2K garantiruet okonchanie tarifnoj voiny?", Jura, no. 3. 2005.

${ }^{10}$ Calculated by: Pavuk O. "Kurs na konteinetizatsiju i konsolidatsiju", Baltic Course, No. 41, Summer 2007. http://www.baltkurs.com/new/rus/index.htm?read=1512

${ }^{11}$ Interfax - Zapad, September 11, 2006. http://www.interfax.by/?id=33\&id_sp=26683\&d=11\&m=09\&y $=2006 \&$ lang $=\mathrm{ru}$

${ }^{12}$ Regnum, April 12, 2006, http://www.regnum.ru/news/622734.html
} 
At the same time, a number of positive examples of Russian-Lithuanian economic cooperation may be enumerated. Russia and Lithuania managed to protect interests of the Russian metallurgic industry, through providing additional export quotas for service centres of the Russian companies in Lithuania (and Latvia) after EU enlargement. ${ }^{13}$ Reportedly, the Russian steel company "Mechel" acquired the Kaunas metal processing factory "Nemunas." However, the opportunity of penetration to Europe through the markets of "new-comers" was articulated by experts in Russia, ${ }^{14}$ in practice few companies utilized it like the aforementioned "Mechel" or "Konversbank" which bought one of the largest retail banks in Lithuania - "Snoras" bank.

At the same time, in spite of certain worries related to possible negative implications of EU enlargement for Russian-Baltic economic relationships, those economists were true who assessed that these implications would rather be of marginal influence. In particular, the share of Lithuania in Russia's trade turnover has not changed substantially, constituting in 2005 about $1.4 \%$, and in May - December 2004 it was 1.3\%, ${ }^{15}$ while the growth of absolute figures was compatible with the total increase in Russian foreign trade.

\section{Foreign Policy}

As mentioned before, though relations with Lithuania cannot be qualified as a top priority of Russian foreign policy. Lithuania is gaining importance through various contexts of a broader foreign policy agenda meaning Russia's Baltic policy, the Kaliningrad problematique, and relationships with the USA and European Union. The impact vector of these aspects is both diverse and controversial.

\subsection{Russia's Baltic Policy}

Moscow's Baltic policy has been shaping a controversial context for Russian-Lithuanian relations. On one hand, the notion of the "Baltic states" has acquired a negative sense arising from the ideas of discrimination against Russian ethnic minorities, NATO enlargement, and attempts to "rewrite history" or to glorify some of its unsavoury periods, as well as from simple nostalgia over the late USSR. Pribaltika - the Soviet name for the three Baltic republics - obtained a certain revanchist connotation. On the other hand, in Russia's Baltic policy, Lithuania has always enjoyed the place of "most favoured" Baltic nation.

The evolution of Russia's policy towards the Baltic States has gone

\footnotetext{
${ }^{13}$ Joint Statement on EU Enlargement and EU-Russia Relations. Luxemburg, April 27, 2004. http://ec.europa. eu/comm/external_relations/russia/russia_docs/js_elarg_270404.htm

14 "Rossiia i Pribaltika II. Report", Moscow: Council on Foreign and Security Policy (SVOP), 1999, http:// www.svop.ru/live/materials.asp?m id=6883\&r id $=6915$

${ }^{15}$ Based on data of the Federal Customs Service of the Russian Federation, http://www. customs.ru/ru/stats/arkhiv-stats-new/popup.php?id286=125
} 
through several stages. During the years 1989 - 1991 the Russian Federation (RSFSR) forged a tactical alliance with Lithuanian, Latvian and Estonian republics in opposing the Soviet leadership. However, their interests began to diverge after the Soviet Union collapsed and Russia faced the need to develop its new foreign policy course. At that time, Russia sought to preserve the elements of the Soviet superpower grandeur by prioritizing global, over narrow, regional interests.

On one hand, Moscow agreed to withdraw Russian troops from Lithuania by the end of 1993 which was faster than from Latvia or Estonia. This signalled an emerging differentiation of Russia's approaches towards the Baltic States. On the other hand, Lithuania, on a par with other Baltic states, became a target for Russia's coercive policies. The winter of 1992-1993 demonstrated the ability of Moscow to wield its economic power, including the "energy supplies" card. ${ }^{16}$

At the doctrinal level, the mentioned differentiation was stipulated in Russia's "Long-term Strategy of Relations with the Baltic States" published in early 1996. By that time, Russian troops had been fully withdrawn and Moscow's major concerns came to be the rights of Russian-speaking minorities and the prevention of the Baltic States' accession to NATO. The "Strategy" was premised on distinguishing among the Baltic countries. Russia was prepared to forge economic ties and good-neighbourly relations, including the signing of border treaties, if the Baltic states committed to fully observing minority rights and promised to forgo NATO membership. As long as Lithuania did not create problems for ethnic Russians to obtain citizenship, and was engaged with Russia on the Kaliningrad issue, Vilnius was touted by Moscow as an example for other Baltic States to follow while the main Russian criticism was directed at Latvia and Estonia.

During this period, Moscow and Vilnius arranged the regime of Russian military transit through Lithuania. In 1997, the two sides signed agreements on their borders and delimitation of the sea shelf. Similar agreements between Russia and other Baltic States were initialled but never officially signed by 2006. It is worth noting that President Yeltsin signed the border agreement with Lithuania despite objections from the Russian State Duma which warned that it would fail the ratification. ${ }^{17}$ Duma deputies raised the issues of Russian transit to the Kaliningrad region across Lithuania, Vilnius' aspirations to join NATO, and even the rights of Russian-speaking minorities. They were also invoking the controversial inclusion of the Klaipeda (Memel) region into Lithuania after World War II. The border treaty with Lithuania was only ratified in 2003, as part of a package that included agreements on the Kaliningrad transit regime. In contrast to Estonia, Lithuania (and also Latvia) was granted most-favourednation (MFN) status in trade with Russia.

\footnotetext{
${ }^{16}$ Vitkus G., "Lithuanian-Russian Relations in 1990-1995. A Study of Lithuanian Foreign Policy", Untersuchungen des FKKS an der Universität Mannheim, 12/1996, p. 17: http://www.uni-mannheim.de/fkks/fkks12. pdf

${ }^{17}$ See: Address of the State Duma to President of the Russian Federation on planned signing of the Border Treaty between the Russian Federation and the Republic of Lithuania], adopted September 26, 1997, http:// www.akdi.ru/gd/post/19352GD.htm - in Russian
} 
Along with coercion, Moscow began to employ tactics of engagement and reassurance. In 1997, Russia proposed multilateral security guarantees to the Baltic States in return for their forgoing of the NATO option. Speaking at a press-conference in Moscow, Lithuanian President A. Brazauskas voiced his discontent with a "hasty rejection of security guarantees offered by the Russian president." However, the three Baltic leaders soon declared the Russian proposal unacceptable because their countries were hoping to obtain security guarantees by integrating into Euro-Atlantic institutions. This did not stop top Russian officials (President B. Yeltsin, Prime-Minister V. Chernomyrdin and Foreign Minister E. Primakov) from pressing ahead with this initiative. As its first move, Russia announced that it was reducing armed forces by 40 percent in the North-Western region, including Kaliningrad oblast. Yet this unilateral initiative failed to impress foreign experts who considered it inevitable in light of the crisis that afflicted the Russian military.

The financial default of August 1998 led to escalation of the domestic political crisis in Russia, predefining concentration on economic issues and setting up a period of "peripherization" of the Baltic issue in Russian foreign policy. Russia quite droopingly reacted on a politically motivated deal on privatizing the MN refinery and adoption by the outgoing Seimas the Law on Compensation for the Damage Caused by Unlawful Acts of State Authorities (2000). This period clearly elicited Russia's inability to coordinate foreign policy activities and economic interests of Russian companies abroad. This resulted in a growing temptation for some companies to pursue their own policies, which often were not corresponded to Russian national interests.

A growth of Russia's activism in Baltic policy became a result of relative macroeconomic and political stabilization after V. Putin ensured his presidency. The content of the new stage was characterized by a number of experts as "pragmatization". ${ }^{18}$ The role of economic factors in Russia's Baltic policy increased, Russia acknowledged the unavoidability of a NATO enlargement to the Baltic States, and with moderate optimism was expecting the enlargement of the EU, pursuing a strategy of damage minimization. As a result, such a problematic issue in bilateral relations as the signing (with Estonia and Latvia) and ratification (with Lithuania) of border treaties, which were treated in Russia as an instrument of containing their accession to NATO and the EU, lost its former relevance.

The accents in such an important issue as defending the rights of national minorities have been changing as well. In interview with Finnish journalists in September 2001 V. Putin claimed that he "does not intend to make a problem out of the status of the Russian-speaking population in the Baltic States, which hinders the development of intergovernmental relations, because this would be to the detriment of Russian themselves living in the Baltic States."19 The domestic political changes in the Baltic States, as well, were to improve

\footnotetext{
${ }^{18}$ Cf., e.g.: "Rossiia i Baltia: 2010. Report". Moscow: Foundation for Prospective Studies and Initiatives, April 2003, http://www.psifoundation.ru/publications/2003/05/baltika1.htm

${ }^{19}$ Interview of V.Putin to Helsingen Sanomat, September 1, 2001.
} 
a background of Russian-Baltic relations. In Estonia a moderate former head of the ESSR A. Ruutel was elected as a President, in Lithuania a left-center coalition of A. Brazauskas was created. There was a hope that the Baltic States in lieu of strengthening the anti-Russian vector in NATO and the EU would prefer employing a role of a bridge between Russia and the West.

This period is marked by the active development of Russian-Lithuanian political dialogue. In the end of March 2001, Lithuanian President V. Adamkus made an official visit to Moscow and Kaliningrad. Though, in spite of the efforts undertaken by Lithuanian diplomats and other officials, the border treaties had not been ratified on the eve of the visit and the joint Russian-Lithuanian Declaration was signed. ${ }^{20}$ In this document Russia implicitly recognized the right of Lithuania to become a member of NATO (agreeing that each state has its right to choose the way of providing security with parallel obligation not to strengthen security at the expense of other states) and promised to proceed with efforts aimed at ratifying border treaties. The very fact of signing this declaration demonstrated a qualitatively higher level of mutual understanding in bilateral relationships in comparison with other Baltic States (the drafts of Political Declarations with Latvia and Estonia proposed by Russia in spring were rejected by Riga and Tallinn).

The election "of the person who had for many years lived and studied in St.-Petersburg ${ }^{\prime 21}$ R. Paksas as a President of Lithuania in 2003 gave a chance to further the progress in Russian-Lithuanian relations. The press-service for the Kremlin at least twice informed about direct phone conversations between R. Paksas and V. Putin. Besides, the Russian President in one of the addresses emphasized a personal role of R. Paksas: "For some time past...Russian-Lithuanian relations have reached a qualitatively new level of understanding and mutually beneficial cooperation. In this your personal contribution is obvious." 22 The statement of R. Paksas on the meeting of Lithuanian ambassadors indicated his intention to pursue a more balanced foreign policy line: "Lithuania has accumulated considerable experience of co-operation with Russia's leadership and Kaliningrad region of Russia. It would be useful to build on this experience in developing co-operation with other, first of all Northwest, regions of Russia." ${ }^{23}$ The proposals on the "northwest initiative" were positively met in Russia, including regional authorities of Russia's North West. Unfortunately, due to subjective reasons and the consequent political crisis in Lithuania, it was not further elaborated.

Another side of Russian's Baltic policy "pragmatization" manifested in the acceleration of measures, ended at the diminishing transit dependence from the ports of the Baltic States, inherited from USSR. The started construction of

\footnotetext{
${ }^{20} \mathrm{http}: / /$ www.kremlin.ru/text/psmes/2001/03/32255.shtml

${ }^{21}$ Words of V.Putin on Russia-EU Summit, St.-Petersburg, May 31, 2003. http://www.kremlin.ru/text/appears/2003/05/47580.shtml

${ }^{22}$ Press-release of Press-service of President of Russia. 16 February, 2004. http://www.kremlin.ru/text/ psmes/2004/02/60665.shtml

${ }^{23}$ Speech by H. E. Mr. Rolandas Paksas, President of the Republic of Lithuania, during the meeting with the Lithuanian Diplomatic Corps. February 27, 2004, http://paksas.president.lt/en/one.phtml?id=3602
} 
the Baltic Pipeline System (BPS) to the new port of Primorsk (the Leningrad Oblast) became a quintessence of this line. Simultaneously with diversification of its transit flows, Russia tends to take under control the transit infrastructure of the Baltic States, thus ensuring itself from probable changes of domestic political conjuncture in these countries. The decision on the cancellation of oil transit through the pipeline towards Latvian Ventspils, adopted at the end of 2002 and ultimately fulfilled in 2003, was advantageous for Lithuania and resulted in a reorientation of oil flows to the Butinge terminal. Since this period, Russia's policy of protecting the interests of Russian companies abroad is getting more consistent.

The process of preparation and the accession of Lithuania alongside with other Baltic States to NATO and the EU resulted in the erosion of Russia's Baltic policy agenda. On the one hand, it failed to become a comprehensive policy line, while its instruments (such as differentiation) proved to be ineffective. In particular, it failed to prevent NATO enlargement and significantly improve the situation with Russian-speaking minorities in Latvia and Estonia. On the other hand, Russia has been gradually realizing that in the forthcoming perspective the negative stereotypes of mutual perception will hardly be overcome, while economic cooperation may become not a result but a condition for improving relationships on the political level. Besides, with account to a sustainable economic record and growing international influence, Russia became less cautious that some concessions on its part would be interpreted as an indicator of its weakness rather than a goodwill gesture. So, the elements of reassurance without engagement in Russia's policy towards the Baltic States have appeared. It stipulates a more individual approach to all three Baltic States, thus weakening the impact of the policy towards the Baltics in general for Russian-Lithuanian relations. At the same time the weight of Russia-West relationships, including the Kaliningrad issue, has increased.

\subsection{Kaliningrad}

Cooperation on Kaliningrad has traditionally been a top issue in the agenda of Russian-Lithuanian relationships, as soon it corresponds to interests of both Russia and Lithuania. Russia is interested in keeping an indivisibility of its political and economic, information as well as cultural and humanitarian space, with the Kaliningrad enclave. This is a prerequisite for preserving territorial integrity and sovereignty, no matter how the role of these definitions might be criticized in the West. Among the natural priorities of Lithuania, related to Kaliningrad, the Swedish researcher I. Oldberg emphasized economic interests (utilizing the advantages of the Kaliningrad Oblast as a "bridgehead" for penetration into the Russian market), sustaining cooperative modus operandi in relations with Russia on the eve of accession to EU and NATO and after, playing the role of a channel for EU policy towards Kaliningrad, beneficial in terms of the political emancipation of Lithuania in regional context and 
in European politics in general. ${ }^{24}$ Indeed, the Kaliningrad problematique has become a stabilizing factor in relations with Russia, the interaction on which was not disrupted even in the periods of the largest tensions in bilateral relations, in particular in 1999-2000. As a result of such cooperation, in February 2000, the Nida Initiative aimed at making joint projects in the priority fields of the Northern Dimension Action Plan was proposed.

Actualization of the Kaliningrad problematique was caused by the pending May 2004 enlargement of the EU and Lithuania's accidence to the Schengen Agreement. It made impossible the preserving of the earlier acting provisions of transit for Russian citizens to/from the Kaliningrad Oblast through the territory of Lithuania. As a possible solution, Russia suggested to conclude a special Russian-Lithuanian agreement which would codify a preferential fashion of relationships on Kaliningrad as a precondition for ratification of border treaties. But these tactics appeared to be of little effectiveness since the position of Lithuania was objectively restricted by the approved terms in relation to accession to the EU (acquis communautaire). It must be mentioned that Lithuania came to the European Commission with the initiative of making exceptions from Schengen regulations for Kaliningraders, but it aroused negative reaction in Brussels.

Some observers in Russia suggested that Lithuania intentionally tried to propose initially unacceptable suggestions to Brussels in order to get rid of the responsibility for settling the transit and visa issue. The Deputy Head of the Russian MFA, E. Gusarov, characterized the ambiguity of Lithuanian policy in the following statement: "The Lithuanian position seems to contain a certain slyness... they are screening themselves behind the position of the European Union. At the same time, there is an objective interest." ${ }^{25}$ Indeed, Lithuania had a specific interest in preserving the maximally favourable regime in regards to visiting the Kaliningrad Oblast for Lithuanian citizens due in account to the large-scale economic and humanitarian links within the region. It was not a surprise that Lithuania, at higher levels, suggested the introduction of magnet cards which would facilitate border crossing for both Kaliningrad and Lithuanian residents.

Anyhow, the main part of the negotiation process on Kaliningrad was gradually transferred from the technical and bureaucratic levels, to the highest political level of relations between the EU and Russia. Russian diplomacy once again had to resort to tactics of bilateral contacts with the leading countries of the EU. This was in order to achieve a long-expected compromise by the summit between Russia and the EU (November 2002, Brussels). It stipulated the introduction of facilitated (railway) travel documents (F(R)TD) for land and railway transit through the Lithuanian territory. The Russian-European political agreements were then put into practical terms in the framework of the Russian-Lithuanian dialogue during the winter/spring of 2002-2003. Though

\footnotetext{
${ }^{24}$ Oldber I., "Kaliningrad: Russian exclave, European enclave", Stockholm: Swedish Defense Research Agency, June 2001, p. 43.

${ }^{25}$ Minutes of the State Duma session, June 19, 2002, http://www.akdi.ru
} 
this process was successfully finalized by July 2003, once again it demonstrated a shortage of trust in the Russian-Lithuanian relations which derived inter alia from the impact of negative stereotypes of mutual perception. So, because of this, Lithuania insisted on a prior ratification of the border treaties, while on the other hand Russia at first proposed to work out a final form of implementation of the RF-EU agreement alleging that a "representative of Lithuania adopted a position, which varies from the agreements, achieved on the summit RussiaEU." ${ }^{26}$ Additional tensions were caused as well by the incidents on Lithuania's borders with the Kaliningrad Oblast and Belarus, referred to as unacceptable from the Russian point of view, conduct of Lithuanian border guards while checking travel documents of train passengers.

Eventually the mechanism of FTD - FRTD came into force, when Russia not only ratified the Treaties on Border and Delineation of the Sea Shelf, but as well signed and ratified the Agreement on Readmission of Illegal Migrants. The latter has become the first international document of this kind for Russia. However, despite the bravura statements of all involved parties that the transit is functioning efficiently and does not make problems, the real spill over of the visa/transit negotiation process on a broader context of bilateral relations is hardly positive. The achieved compromise has an asymmetric character, while the very FTD intrinsically is a quasi-visa ${ }^{27}$ and number of people who have chosen railway transport continued to fall down. ${ }^{28}$ The Lithuanian side persistently modified the conditions for transit by the requirement of an insurance policy or prohibition of transit for "potent" pharmaceuticals. Some Russian experts believe that Russia was to have rejected the Agreement on such terms and organized a full-fledged air-bridge to Kaliningrad. According to the Situation Analysis of the Council for Foreign and Security Policy (SVOP), though both parties will abstain from harsh statements, the issue will continue to be a source of aggravation in Russian-European relations. ${ }^{29}$ Of course, all parties recognize the sovereign right of Lithuania to know who is crossing its territory. At the same time, the currently functioning transit regime hardly corresponds to the "threat" which this transit poses. In particular, no single illegal migrant has left a Russian transit train and has been deported according to the provisions of the Agreement on Readmission.

Alongside with passenger transit, the issues of cargo and military transit seem to be far from finding their final resolution. In spite of the assurances made by Vilnius before the EU enlargement, transit towards Kaliningrad has

\footnotetext{
${ }^{26}$ Stenography of answers of Minister of Foreign Affairs of the Russian Federation I. Ivanov after the address in the Council of Federaion, Federal Assembly. March 26, 2003, http://www.mid.ru/brp_4.nsf/ sps/8BBCEA21DC27333243256CF50063BE92

${ }^{27}$ The consular service of Lithuania informs, that "FTD are made equivalent to visas, which does not allow entrance to other country", http://amb.urm.lt/kaliningradas/ambtopmenuitems.php?TopMenuID $=1200 \& \mathrm{Si}$ teID $=86 \&$ LangID $=3$

${ }^{28}$ This trend tends to overcome only in 2006. Cf.: Nilov A., "Na Kaliningradskoi' zheleznoi' doroge vyros objem grozuperevozok i passazhiropotok", http://amb.urm.lt/kaliningradas/ambtopmenuitems.php?TopM enuID $=1200 \&$ SiteID $=86 \&$ LangID $=3$

29 "Otnosheniia Rossii i Evropei'skogo soiuza: Sovremennaia situaciia i perspektivy. Situation Analysis". Under supervision of S. Karaganov, http://www.globalaffairs.ru/docs/report.doc
} 
become virtually more expensive and complicated. The qualitative increase in transit through Lithuania is masking its quality, this featured by a fall in trade turnover between the Kaliningrad Oblast and other Russia' regions. ${ }^{30}$ The progress on signing a bilateral treaty on military transit is also not expected, though the prospects of such document were indirectly envisioned by the Joint Russian-Lithuanian Statement (Moscow, March 30, 2001). So, the Government of Lithuania by de facto continues to regulate Russian military transit on a unilateral basis. Besides, it is a known and rather negative stance on behalf of Lithuania on the issue of organizing non-stop high-speed railway communication to the Kaliningrad Oblast. There are uncertainties on how the transit regime to/from the Kaliningrad Oblast will be arranged after abolition of internal borders in the EU, which may happen by 2008, after Lithuania ultimately joins the Schengen space.

Set against this background, Vilnius and Brussels have periodically encouraged Russia not to get hung up about the transit aspect and pay more attention instead to economic development on the basis of a more cooperative approach towards involvement of the European Union. At the same time, it is clear that the interests and policies of Russia, the EU, and also Lithuania on the economic future of Kaliningrad are divergent. ${ }^{31}$ All of this, if it is desired, might be interpreted in the context of the implementation by Vilnius and Brussels of the policy line aimed at "natural" dissociation of the Kaliningrad Oblast from the Russian Federation. The officially stressed rhetoric on the inherent belongingness of this region to Russia is accompanied by low-profile suffocation of arteries, connecting Kaliningrad with the mainland Russia, and providing more favourable conditions for boosting cooperation with the neighbouring countries. Such an interpretation of Lithuania's and the EU's positions, conditions Russia's response and has been expressed in a form of an emphasized demonstration of opportunities to decrease transit dependence on Lithuania (presentation of the railway ferry Ust-Luga - Baltijsk presided over by V. Putin) or the introduction of a relatively large minimal volume of investment to be accepted into the Special Economic Zone (SEZ) regime, while Lithuania is represented in the region mostly by small and medium enterprises.

In general, the impact vector of the Kaliningrad problematique on Russian-Lithuanian relations is quite controversial. Positively, it has contributed to sustaining tonus in bilateral dialogue in 1990;s and 2000's and also the elaboration of experience and mechanisms of interaction between Vilnius - Moscow and Vilnius - Kaliningrad, and all of this could then be translated into other spheres of cooperation. Negatively, it indicated that the fears on real intentions of each other are still in force, thus weakening balance (including the psychological one) between cooperation and competition in favour of the latter and playing the role of a long-run "coolant" for bilateral relations.

\footnotetext{
30 "Kak sdelat' bolee effektivnoi' sistemu sotrudnichestva Rossii i ES", Moscow: Probel -2000, 2005. p. 39-41.

${ }^{31}$ Karabeshkin L. "Rossiia, ES i problema Kaliningrada", Evropei skaia bezopasnost': sobytiia, otsenki, prognozy, no. 3 (19). Moscow: INION RAS, 2006. p. 7-9 (in Russian).
} 


\subsection{Relations Between Russia and the West as a Factor for Russian-Lithuanian Relations}

The past recent years have demonstrated the increasingly vivid trend of the growing impact of Russia's relationships with the USA and the EU on the context of Russia's relations with the Baltic States. In the beginning of 1990's, the West and first of all the USA were taking Russia's regional concerns into consideration, e.g. on the Baltic membership in NATO. In addition, it is better to tell not about the American factor in Russian-Lithuanian relations at that period, but rather about Lithuanian (or the Baltic) factor in Russian-American relationships. At that time Washington was not ready to mar relations with Russia on this issue. But already in the second half of 1990's the negative Russian attitude towards NATO enlargement was not considered. Though Russia tried to draw "red lines," making relationships with the West dependent on the membership of the Baltic States in NATO, it was not interested in open confrontation and preserved serious financial dependence from the West. In its turn, the latter did not make harsh steps such as: proclaiming the policy of "open doors" for membership in the Alliance the precise parameters and timing of the next wave of enlargement were not announced. The Baltic Charter, signed in 1999 between the USA and the Baltics, was interpreted both as a waiting room and a a substitute accession of the Baltic States to NATO. But even without this issue the Russian-Western relations tended to deteriorate.

During the first presidency of V. Putin, the Russian foreign policy was gradually drifting from the "Primakov's Doctrine," embarking on a course of revitalization of dialogue between the USA and EU. It is also worth mentioning that the current Russian President, being yet a "successor" to B. Yeltsin, among one of the instruments of international legitimization used the idea of transforming the Kaliningrad Oblast into the "pilot region" for Russian-European cooperation. This was outlined in the Mid-Term Strategy of Relationships with the European Union presented by than Prime-Minister V. Putin in Helsinki (in October 1999). Though the "pilotness" has not been officially conceptualized, it indicated the desire of the new Russian leadership to seek for rapprochement with Europe.

The terrorist attacks of 9/11 led to serious improvement of relations between Moscow and Washington, based on the common interest of combating international terrorism. As a kind of compensation for NATO enlargement, Russia received a renewed format of the Russia-NATO dialogue - the new NATO-Russia Council (NRC) was established in May 2002. This period was marked by positive dynamics in Russian-Baltic and Russian-Lithuanian relations as well. Lithuania underscored its desire to enhance the development of contacts between Russia and NATO. On the hearings in the House of Representatives of the U.S. Congress, the Lithuanian Ambassador Vygaudas Ušackas emphasized that accession of the Baltic States to NATO would "strengthen the 
stability in Europe as well as contribute to a new relationship which is being shaped between Russia and NATO, which we certainly welcome." ${ }^{\prime 32}$

But already, since 2003, the crisis symptoms both in Russian-European and Russian-American relationships manifested themselves. The ambiguous Russian position on Iraq, diverging approaches to definitions of a terrorist threat, "color" revolutions in CIS countries, the growing presence of the West on the post-Soviet space, the YUKOS case, and also different approaches to energy security, composed only a narrow list of the newly emerged controversies. Russia's Western counterparts specified the fact that true partners should adhere to common values alongside with common interests. As a pattern, Russia was called to adopt Western standards of democracy and human rights. The Russian political elite, in turn, insisted on a vision of democracy for Russia which crystallized into a concept of "sovereign democracy."

The exacerbation of relationships between Russia and the West tended to aggravate the environment for relationships with the Baltic States. After accession to the EU and NATO they were looking for a niche in Euro-Atlantic politics. Feeling the demand for critics of Russia on the part of the West, the Baltic countries readily met it. The active role of Valdas Adamkus in the Orange Revolution in Ukraine, the profound support of the new ruling regime in Georgia, the denial to attend celebrations for the $60^{\text {th }}$ Anniversary of the Great Victory in Moscow (May 9, 2005), and exposure of Russian "spies" serving in the diplomatic corps had not gone unnoticed in Russia.

Such a policy of the neighbour could hardly be welcomed in Moscow. There were no fears about the excessive growth of Lithuanian influence on the post-Soviet space. The main anxiety was caused by the trend of growing American, and to a lesser extent, European presence in the CIS where Lithuania positioned itself as a "subcontractor" of carrying it out. The Baltic States, as the first former Soviet Republics accessed to the EU and NATO, opened a symbolic door for further eastward penetration of Euro-Atlantic groupings. The assurances by Washington, that further NATO enlargement is not aimed at undermining Russia's interests, carry little conviction for the Russian political elite.

As a response Russia opted for tactics of "marginalization" of the Baltic States in international context. On the one hand, it was focused on the cultivation of a negative image of the Baltic States, which are used to violate human rights and turn in to a "hero" the crimes of Nazism and revise the results of WWII. On the other hand, Russia revived the tactics of contrasting "old" and "new" Europe. The logics of "marginalization" predetermined the non-invitation of Lithuanian (and Polish) leaders for celebrations of the $750^{\text {th }}$ Anniversary of Kaliningrad (2005) or promotion of the project of the North European Gas Pipeline from Russia to Germany bypassing territories of the Baltic States and Poland.

\footnotetext{
${ }^{32}$ NATO Enlargement: A View from the Candidate Countries. Hearings before the Subcommittee on Europe, Committee on International Relations. House of Representatives. $107^{\text {th }}$ Congress, Second session, serial no. 107-8, May 1, 2002, p. 43.
} 


\section{Domestic Context of Foreign Policy}

At the very beginning of the process of nation-state building, Lithuania like many other newly emerged or transition countries, employed the model of the so called "conflict ethnic conduct," which consisted of utilizing the image of the outside enemy for domestic consolidation and attracting political attention and economic assistance of the countries of a "democratic core." It is not surprising, that it is the former metropolis which was selected for this role. As far as the Lithuanian statehood was strengthening, this mobilizing mechanism was gradually losing its importance. But even now Russia continues to stay a significant "other" or a negative point of reference.

Evaldas Nekrašas qualitatively describes relations with Russia as vulnerable, considering that Lithuania's membership in the EU and NATO has not eliminated but rather added to the escalation of Russia militarily and politically as well as the economic threat. ${ }^{33}$ Simultaneously, there are strong doubts about the predictability of Russian policy. This is conditioned not only by the growing authoritarianism, mentioned by Lithuanian journalists and political analysts. In fact, in spite of Lithuania's claims to be an expert in the post-Soviet region, Russia is getting a terra incognita for it, while the serious analysis of political and economic processes in Russia are often replaced by ideologised rhetoric.

The cautious attitude to Russia among Lithuanian political elite is rooted in public opinion, but at the same time is fuelling it up. According to the public polls, $46.2 \%$ of Lithuanians believe that Russia represents a threat for their country, while the opposite opinion is shared by $39.1 \% .{ }^{34}$ Unfortunately, the thesis on the all-permeating "Moscow hand" is a meaningful argument in settling issues of domestic political and economic agenda, which works effectively without solid evidences. It is worth reminding the stories of R. Paksas's impeachment, the political neutralization of V. Uspasskih, and the most recent fire on the MN refinery. It is remarkable, that the impact of the "Moscow hand" is a priori adversarial, while nobody is afraid of the "Washington hand", though methods and provisional damage of both can be similar. One may remember the loss brought about by the deal with American company "Williams" which was lobbied by authorities of the USA. The discussion about a new informational type of threat that originated in the East has been revitalized recently. The point is that Russian audiovisual content aspires to occupy a growing share of Lithuanian TV channels.

The image of Russia as a source of threat naturally affects the defining of foreign policy ends of Lithuania, augmenting measures on limiting Russia's influence and fencing from it. Such measures, on the one hand, include strengthening Transatlantic links and relationships with Washington, and on the other hand, providing political and economic assistance to certain CIS countries, in particular through supporting their aspirations for NATO and EU membership

\footnotetext{
${ }^{33}$ Nekrašas E., "Lithuanian Foreign Policy: Achievements, Concepts and Predicaments", Lithuanian Foreign Policy Review, no. 1-2. 2004, p. 28-35.

${ }^{34}$ BNS, October 19, 2006.
} 
(from this perspective, Lithuania not only serves American interest on the postSoviet space, but as well has its own one). There is a widely spread assumption in Lithuania, that the country cannot entirely rely on Europe in ensuring its security, because the largest countries of "old Europe" could make a deal with Russia, behind the backs of small states, thus betraying their interests.

Respectively, the Lithuanian image in Russia is beginning to be perceived in the context of a newly emerging cordon sanitaire around the perimeter of Russia's borders. Whereby in public opinion, Lithuania has steadily occupied the highest ranks in the "hostility index" - both in 2005 and 2006 Lithuania was qualified by $42 \%$ of respondents as adverse to Russia $\left(2^{\text {nd }}-3^{\text {rd }}\right.$ place after Latvia and Georgia). ${ }^{35}$

One more significant factor having roots in domestic discourse and affecting foreign policy refers to different interpretations of $X X$ century history. Lithuania tried to inscribe the discussion of historic issues into the general context of a bilateral dialogue. Russia persistently rejected such attempts (V. Putin stated that: "...Some of our historical heritage is very complex, but we wouldn't like to see it additionally politicized"36) and emphasized the thesis about the voluntary character of inclusion of the Baltic States into USSR in 1940. In fact, this does not mean that approaches to evaluation in a number of historic events in Russia and Lithuania are ultimately incompatible. The main reason for Russia's rigid position is disbelief on the part of the political elite, that acknowledgement of the occupation and bringing official apologies will be used by Lithuania for improving bilateral relations. Vice versa, the set perception stereotype gives one ground to expect their further deterioration, producing new condemnations and adding legitimacy to the claims of financial compensations.

\section{Conclusion}

The ambassador of the Republic of Lithuania in Russia, R. Šidlauskas, in one of his interviews characterized Russian-Lithuanian relations as smooth, in a legal and practical sense, specifying that border issues have been settled, treaties have been ratified, and problems that would need unachievable solutions are lacking. Simultaneously, he pointed out a negative psychological environment. ${ }^{37}$ The problems associated with negative perceptions and stereotypes affect all spheres of Russian-Lithuanian relations being - economic, foreign policies, and their domestic context - this often playing a role of an additional irritant and constraint for their development. Often this results in assessing steps of each other in terms of a zero sum game. Nevertheless, the 15 years

\footnotetext{
${ }^{35}$ Golov A., "Strany-druz'ia i strany-vragi dlia Rossii: peremeny za god", June 5, 2006, http://www.levada. ru/press/2006060502.html

${ }^{36}$ Vladimir Putin had a press briefing at the International Press Centre in Strelna, St Petersburg. July 17, 2006. http://www.mid.ru/brp 4.nsf/sps/6831F8C1E83F4664C32571AE002A97E6

${ }^{37}$ BNS, 17 May 2006.
} 
history of the bilateral relations has demonstrated that as a rule, the balance between pragmatic interests and stereotypes drifts in favour of the former. The accumulated experience and elaborated mechanisms of interaction, mutually accepted rules of game, and also the foremost rational estimation of benefits of practical cooperation in various spheres from economy to ecology constitute an objective basis for it.

In the long-term optimistic scenario, the factor of negative mutual perceptions is going to weaken this thus decreasing the opportunities for utilizing it in domestic politics. Relationships between Russia, the EU and the USA, alongside with keeping elements of competition, are doomed for cooperation and probably partnership, thus reducing the demand for criticism towards Russia. So, because of this, the Baltic States will confront with necessity of building a cooperative model of relationships with their Eastern neighbour. The development of economic and humanitarian links, in particular at a regional level, serves as a precondition for overwhelming mutually negative images and fostering political dialogue between Russia and Lithuania. 